\title{
Interim Pastoral Skills as a Resource for Library Leadership Transition
}

Carisse Mickey Berryhill, Abilene Christian University

David E. Cox, New Mexico Tech

\begin{abstract}
David E. Cox, a veteran pastoral minister specializing in interim ministry, and who is now a library leader, and Carisse M. Berryhill, a library science professor, explore how skills used by interim pastors can be applied by interim leaders or new directors to successfully lead libraries making the transition to new leadership. Cox recommends using a system-based strategy that moves through five steps: coming to terms with history, discovering a new identity, allowing for needed leadership change, reaffirming community with stakeholders, and commitment to new directions in programs and services.
\end{abstract}

This conversation came about because, before becoming director at New Mexico Tech, Dr. Cox had many years of experience as an interim pastor. Dr. Berryhill wondered how he might see the skills of interim pastors as useful to interim or new leaders in libraries, drawing on his experience as a new library director with a background in professional interim pastoral work. She also had recently interviewed a presently serving interim library director. Questions below were posed by Dr. Berryhill; responses came from Dr. Cox.

Thinking about systems is a useful strategy. Because a system seeks its own balance to perpetuate itself, people in community tend to learn to support the system they are a part of, even if they disagree with it. From this systems perspective, new library leaders can benefit from the process skills routinely used by interim pastors.

How long do interim pastors usually serve?

Interim pastors usually serve a year or two, though I have heard of interim pastorates as short as six months or as long as 48 months. 
I'd like for us to take up your five processes one by one: coming to terms with history, discovering a new identity, allowing for needed leadership change, reaffirming community with stakeholders, and commitment to new directions in programs and services. How have you used these five processes from your previous career in your new setting? Let's begin with coming to terms with history.

\section{COMING TO TERMS WITH HISTORY}

Gaining perspective on its past helps the library prepare for the future, especially when there has been a long tenure, an involuntary departure, and/or conflict with senior leadership.

You need to know the history of the organization, not just by reading reports but by leading the staff at a retreat to create a "history-gram," circulating an outline of the library's history and inviting staff to fill in what they recall.

The interim director I interviewed commented that the new leader would need to listen to everyone but "weed through" the various narratives. Sometimes there is baggage.

Yes, there are always those willing to provide "color commentary," but you need to hear from everyone because these are the people you will be leading.

The second step you listed is carrying out a self-study. How long did this take in your new library, and how did you go about it?

\section{DISCOVERING A NEW IDENTITY}

A library self-study and environmental audit begins the journey by focusing on the library's present reality and future role, leadership, community, collections, programs, and staff.

It took about six months to let the history we had gathered simmer, to dovetail with the mission in the past and let that build up to create new items. It is important to identify your assets and not dwell on your deficits. 
How many people were in the conversation? Didyou do this all at the history-gathering retreat, or in a series of meetings?

My library had twelve staff in the conversation. We had a series of discussions building on each other because we were developing that new identity. As a team, we decided we wanted to up our public and circulation service game, to participate in the dialogue of inquiry, which would be a new emphasis and evolving role. At each meeting the team would discuss how they were sensing the change. We met at least every two weeks, and sometimes more often.

How did you measure your success?

After about a year, a routine annual campus survey affirmed improvement in patrons' perception of the library's quality of personal service.

So your staff had input as to what the change would be and opportunity to report on how they were experiencing it?

Yes, and that led to some people taking on new roles, which is the third process I listed.

\section{ALLOWING FOR NEEDED LEADERSHIP CHANGE:}

A change in the directorship may precipitate changes in internal leadership. Old leaders may take a less active role while new persons become more involved.

People get used to their positions under a previous directorship, especially if it is a lengthy one. How do you transform that? After you have completed the history and environmental scan, you eventually say, "You have great strengths in this area, let's use you more in this area." Some people are better with systems, others with people, others with communication on the website. You allow yourself to have leadership change that is organic, which allows for camaraderie, and people get rid of their fiefdoms.

Did you have some hardline resisters who couldn't let go of a previous identity? 
Yes, but we allowed people to opt in at their own speed. One thing I learned in interim ministry is you can only go as fast as the slowest person adapting to change. Patience is really important.

You don't walk up to a mobile and whack it, or the system flies to pieces. You must take incremental, iterative steps. The person I interviewed told her VPAA that she didn't want to make any changes as an interim. And yet, there were a couple of resignations during her service as the result of staff members' personal needs. And, of course, the COVID-19 pandemic has added a layer of management stress that no one expected. For example, she had a hiring freeze in place.

This year I've had two retirements, one resignation for personal reasons, and three experienced people who took a different job. So newer leaders have to step in. One of my paradigm rules is, "Always listen to the outsider, the new person, because they are going to see it differently than you do."

Maybe this is not a cog railway but an iterative process. I want to askyou about identifying significant relationships and strengthening the sense of ownership, your fourth process point.

\section{REAFFIRMING COMMUNITY WITH STAKEHOLDERS}

Rather than leading from scarcity, the new leader identifies and empowers relationships with people and organizations who are stakeholders to give new life, interaction, and ownership of the library in its community.

Yes, I want all our constituents to feel they have entry into the process. How do we affirm that we are part of a community? I did this by initiating asset-based planning and management. Although it is tempting to focus on your obvious deficits, it is more important to build on your assets, whether those are personalities, positions, or interactivity in the community. When people are talking with you, they are sensing you really do want their opinion, ownership, and empowerment. 
Besides your own staff, whom do you think you spent the most time with?

I created an advisory board with a faculty member from every department, some deans, an associate vice president for academic affairs, and the dean of students. They could say, "When we are interacting with the library, this is our experience." As we implemented changes, we had these people who really wanted it to be better. Instead of saying, "I couldn't get past this point," they would say, "With your help, I got past this and this is where I went!" It totally refocused the conversation.

Is it in your role to talk to donors?

I can. The Advancement Department knows they can ask me to go talk to community members. For example, our school is in Socorro, NM, thirty miles from Ground Zero from the Trinity blast-the first atomic explosion on July 16, 1945. Many of the scientists here remember the event and that no one knew what to expect about the fallout from the explosion. We are collecting oral histories so people can use them to interact with our written material for research.

All right, let's just touch on this last point quickly.

\section{COMMITMENT TO NEW DIRECTIONS IN PROGRAMS AND SER- VICES OFFERED}

Furthering the mission and vision developed through its self-study and environmental audit, the library emerges with a new understanding of new or renewed opportunities for access and service.

The hoped-for result of this process encourages the library to embrace new initiatives in partnership with its newly found leadership and programs.

\section{AUDIENCE QUESTIONS}

How should a former director think about stepping down into a part-time role under a new director after having run the library for a significant period of time? 
My interim dean friend says that her next task is to step back into her previous role in her library without hanging around as a leftover dean.

The former leader needs to have great personal skills. They have to be watchful for opportunities to empower the new director. They should be willing to provide insights as asked. An interim minister, when handing things off, always has to think about, "What will I say? What will help?" in an intentional and compassionate spirit. So a previous leader who is going to remain in a part-time role now needs to say, "I have confidence that you are going to take things forward in ways I never dreamed of. How can I help you succeed?" When I was working in ministry, the interim was required to leave entirely for at least two years. But when a former leader remains in some role, the new leader needs to consider that person as an asset. The new leader needs the confidence to feel comfortable and not compromised. A previous director can be a great stakeholder.

We have a question about carrying out environmental scans.

The environmental scan is not just gathering statistics; it's watching people who are in your library, watching what they do, taking notes, and reviewing those notes to understand the patterns of strength and opportunities for capitalizing on them. 